\title{
Protective factors in the attainment of resilience in persons with disability
}

\section{Faktor protektif dalam pencapaian resiliensi penyandang disabilitas}

\author{
Wiwin Hendriani \\ Faculty of Psychology, Universitas Airlangga \\ Address: Jalan Airlangga No. 4-6, Surabaya, East Java 60286 \\ E-mail: wiwin.hendriani@psikologi.unair.ac.id
}

\begin{abstract}
People who live with a physical disability requires further attention. Living as a disabled person is not easy, especially if the individual was born as a normal person. This study aims to identify the protective factors that play an influential role in the attainment of resilience in individuals who experience physical changes as a disabled person. This research applied the instrumental case study approach. The participants consisted of eight individuals with physical disabilities. The data was gathered using an in-depth interview, while the thematic analysis technique was used in the data analysis. The results show that there were eight protective factors involved in achieving resilience in individuals who experience physical change as a disabled person. The eight factors consist of four external protective factors; social support, psychological intervention, the presence of a source of inspiration and the availability of public facilities for persons with disabilities. There are also four internal protective factors, namely religiosity, the willingness to learn, an awareness of social support, and an awareness of self-identity. The results of this study can be implemented in order to assist in the attainment of resilience among other groups of individuals who also undergo a change of physical condition through the strengthening of the eight protective factors.
\end{abstract}

Keywords: disability; resilience; protective factors

\begin{abstract}
Abstrak
Masyarakat yang mengalami disabilitas atau kecacatan perlu mendapatkan perhatian serius dari semua pihak. Bukan hal yang mudah bagi individu untuk menjalani hari-hari sebagai penyandang disabilitas, terlebih jika sebelumnya pernah merasakan kehidupan dengan kondisi fisik yang tidak terhambat. Penelitian ini bertujuan untuk mengidentifikasi faktor-faktor protektif yang berperan dalam pencapaian resiliensi pada individu yang mengalami perubahan kondisi fisik menjadi penyandang disabilitas. Resiliensi psikologis mencerminkan bagaimana kekuatan dan ketangguhan yang ada dalam diri penyandang disabilitas dalam menghadapi tekanan yang bersumber dari kondisi fisik dan berbagai situasi tidak menyenangkan yang ditemui di masyarakat. Penelitian ini dilaksanakan dengan pendekatan studi kasus instrumental, dengan partisipan terdiri dari delapan orang tunadaksa resilien berusia dewasa yang mengalami disabilitas selepas usia anak. Pengumpulan data dilakukan dengan wawancara mendalam, sedangkan analisis data dilakukan dengan teknik analisis tematik. Hasil penelitian menunjukkan adanya delapan faktor protektif yang berperan dalam pencapaian resiliensi pada individu yang mengalami perubahan kondisi fisik menjadi penyandang disabilitas. Kedelapan faktor tersebut terdiri dari empat faktor protektif eksternal: Dukungan sosial, intervensi psikologis, keberadaan sumber inspirasi, dan ketersediaan fasilitas umum untuk penyandang disabilitas; serta empat faktor protektif internal yaitu religiusitas, kemauan belajar, kesadaran akan dukungan sosial, dan kesadaran akan identitas diri.
\end{abstract}

Kata kunci: disabilitas; resiliensi; faktor protektif

\section{Introduction}

Law No. 4 of 1997 concerning Disabled People defined that not every human lives with normal physical characteristics. There are groups of people who live with a physical disability which requires further attention. In article 1, Law No. 4 of 1997, disabled people are people with physical and/or mental deficiencies which means that they cannot go about average social functions. They are people who are physically disabled, mentally disabled, and physically and mentally disabled (Kasim 2007).

Living as a disabled person is not easy, especially if the individual was born as a normal person 
(Hendriani 2012, Inoy 2012, Winasti 2012, Yudistia 2011). There are a lot of things that could lead to physical and mental deficiencies such as an accident, illness or disease (Inoy 2012, Utomo 2012, Yudistia 2011, Ferrasta 2010, Tarsidi 2008, Yoshida 1993, dan Charmaz 1991).

A sudden disability will have a huge psychological impact on people with disabilities (Tarsidi 2008). They are exposed to significant changes related to their family and social relations, as well as being tied into performing various expected roles in society. They also have to endure physical pain and continuous medical interventions, facing the fact that their daily life is affected, all while often facing an inconvenient response from surrounding society (Inoy 2012, Utomo 2012, Ferrasta 2010).

The disabled person can also experience a lot of discriminative treatment from their surroundings. Their physical condition frequently evokes negative feedback, directly and indirectly (Inoy 2012, Setyawati 2012, Baihaqi 2007, Ototake 2001). Compared to people without a disability, people with a disability have to complete their daily activities through different methods. For instance, a physically disabled person needs to use their foot or mouth to write. A deaf person can only communicate using sign language, and a blind person may touch things around them. These methods can be perceived as odd things. They also have to live as if they were an object that needs to be pitied. Such behaviour originating from the surrounding only increases the disabled person's psychological burden (Setyawati 2012, Yudistia 2011, Baihaqi 2007, Ototake 2001).

Many articles available in mass media or scholarly journals discuss that disabled people still frequently experience discrimination and tend to be excluded from their environment. They face difficulties when accessing public facilities such as education, healthcare services and work opportunities (Yudistia 2011, Baihaqi 2007, Kasim 2007, Fuad 2010). Research conducted by Hendriani in 2006, 2007 and 2008 found that people with a disability even experience discrimination from their family. The frequency of disabled people receiving mistreatment and humiliation makes them often experience continuous negative feelings such as sadness, fear, anger and anxiety.

Individual capabilities in relation to managing their emotions and adapting to the rise in psychological pressure are highly required for a disabled person to recover from any breakdowns. They are expected to manage and recover their emotional stability due to the emotional management that is highly associated with the individual will to survive. Do they choose to continue mourning their situation and pulling themselves away from their social life or do they choose to be resilient, full of acceptance and try to become a proactive and productive agent regardless of their different physical situation?

Olson \& DeFrain (2003) stated that resilience is the most suitable characteristic required to cope with hardship in life. Tugade \& Fredricson (2004) defined resilience as an effective coping mechanism and positive adaptation when facing difficulties and pressure. According to Reivich \& Shatte (2002), resilience is the capacity to cope with trauma and misery positively and productively. Ungar (2004) defined resilience as a term that describes the healthy condition of an individual in a situation which is collectively perceived as harsh and full of pressure.

Psychological resilience reflects individual strength and toughness. This is signified by the willingness to rise after a negative emotional experience. Resilience enables an individual to face and rise from within a stressful situation (Tugade \& Fredricson 2004). Understanding how to achieve resilience will be helpful in formulating an effective approach to guard and increase individual resilience for people with disabilities across a wider spectrum of society (Peters, Leadbeater \& McMahon 2005).

According to Masten (2001), not every individual can display resilience when they face hardship and pressure. Resilience cannot always be achieved, particularly for a person with a disability who was previously living without a disability. Most of them tend to experience psychological pressure. They also lack the confidence to struggle for a better quality of life. As a consequence, many disabled people only rely on one other person for sympathy. For instance, a research study conducted by The Lighthouse International (Tarsidi 2008) found that depressed blind adults tend to refuse rehabilitation assistance even though the treatment could help to lessen their depression. The individual shuts down 
the possibility of psychological recovery and believe that if their sight cannot be recovered, then nothing could lessen their misery.

Tarsidi (2008) observed the characteristics of blind people according to their responses toward their disability and classified them as follows: 1) the group who cannot accept their physical change and who rely on other people and sympathy. Their social relations were tense with negative feelings involved such as anger, pain, disappointment and sadness; 2) the individual group who were quite able to manage their disappointment related to their disability even though at some points, frustration triggered feelings of self-pity and anger; 3 ) the individual group who utilise their disability positively and try to be more productive compared to the period before they endured the disability and 4), the group who found a religious value to their disability. The individuals in the third and fourth groups were identified as having a resilient character.

Even though resilience cannot be achieved easily, there have been several disabled people who have shown evidence of having great coping mechanisms and effective adaptation behaviour against pressure. This behaviour has been found in disabled groups in the research conducted by Hendriani (2007, 2008, 2012), Setyawati (2012), Yudistia (2011), Lee (2008), Baihaqi (2007), Inoue (2006) and Ototake (2001). Regardless of their disability and people's underestimations, these groups choose to stay optimistic and refuse to whine about living their life, blaming nobody regarding their physical situation. There has also been a case of a person with chronic disease who was required to stay in his bed, but who chose to be positive about continuing on with his life, not excluding himself from society and creating innovations with the capabilities that he still has (Ferrasta 2010, Cohen 2008).

The question proposed in this research is 'what factors distinguish the resilience characteristics reflected in a disabled person?' According to Richardson (2002), resilience is influenced by protective factors. Van Breda (2001) found that resilience related to protective factors (individual, social, family, network and institutional security network) is significant. It allows an individual to gain security in their life. Protective factors are a factor that strengthens and provides a positive influence to individuals when they start going ahead with an effective coping strategy to respond to stress. Successful coping and adaptation methods prove the urgency of protective factors (Kalil, 2003). This research will dig deeper and identify the protective factors that play a significant role in relation to an individual who has experienced physical change and become a disable person, in relation to attaining resilience characteristics.

\section{Research Method}

This research applied the qualitative approach when conducting the research. According to Ungar (2003), the qualitative approach is regarded as essential to understanding resilience because of the following reasons: 1) the qualitative approach enables researchers to dig and learn about the relevant protective factors in an individual's life that have not been identified in previous studies; 2) the qualitative method allows researchers to gain a rich and profound description of a specific concept drawn from the resilience phenomena; 3 ) it allows the researcher to gather data from a minority group and 4) it provides the opportunity to construct an understanding about resilience according to the circumstances and characteristics of the participants which could be different according to the research context. Moreover, the individual is a social being that is native to their social and cultural context, thus leading to different characteristics. The author chose an instrumental case study as the research type since it allows the researcher to reach a conclusion that contributes to the development of a theory. This research applied the theory of resilience in the context of disabled people. Data from all of the research subjects was considered to be a union that was collected to address the research question proposed in this study.

The research subjects consisted of 8 disabled people of adult age who first experienced a change in their physical abilities in their teenager years up to adult age (13 years old and beyond). Thus, the 
participants were considered to have a sufficient amount of experience of living without disability. All of the participants were characterised as being a resilient individual. This category was based on Tugade \& Fredricson (2004), who focused on the characteristics of resilient individuals such as optimism, dynamism and enthusiasm in the various things that they experienced in life, such as being open to new experiences, possessing a positive emotional state, being active in developing positive emotions through humour and relaxation and they opening themselves up for social interaction.

The data collection was conducted through an in-depth interview. The thematic analysis technique was applied as the data analysis method. This method enabled the researcher to utilise the information systematically to increase sensitivity and accuracy when understanding the data (Boyatiz 1998). Regarding the instrumental case study research type, the data analysis method applied was datadriven thematic analysis. This analysis was developed by Boyatiz (1998) as a procedure to develop an inductive understanding of the raw data. The researcher will interpret important information from the data and construct their findings in order draw a theoretical contribution from the study. The analysis requires several steps to be undertaken including 1) taking note for all collected data in a systematic way, 2) making an outline from the data, 3) making comparisons and outlining any grouping, 4) building themes and the relevant codes, 5) conducting a findings evaluation and 6) interpreting the results and making a conclusion.

Table 1.

List of the Participants

\begin{tabular}{cccc}
\hline Initials & $\begin{array}{c}\text { Age on the } \\
\text { interview (=years) }\end{array}$ & $\begin{array}{c}\text { Age on experienced } \\
\text { disability for the first } \\
\text { time (=years) }\end{array}$ & $\begin{array}{c}\text { Duration of being } \\
\text { disabled person } \\
\text { (=years) }\end{array}$ \\
\hline FPS & 58 & 51 & 7 \\
MU & 49 & 45 & 4 \\
TS & 45 & 23 & 22 \\
SPM & 35 & 29 & 6 \\
MRD & 47 & 41 & 6 \\
DYK & 27 & 22 & 5 \\
SDR & 46 & 43 & 3 \\
LST & 34 & 18 & 16 \\
\hline
\end{tabular}

\section{Result and Discussion}

Protective factors are a factor that strengthens the individual, providing positive feedback to the individuals so then they can find an effective alternative to avoid prolonged stress (Kalil, 2003). Protective factors protect the individual from experiencing advancing psychological problems and encouraging the occurrence of a protective strategy in two paths; external protective factors originate from outside the individuals, such as from their family and the social environment, and internal protective factors come from the individual themselves.

External protective factors consist of 1) social support, 2) psychological interventions, 3) the presence of a source of inspiration and 4) the availability of public facilities suitable for a disabled person. On the other hand, internal protective factors involve 1) religiosity, 2) the willingness to learn, 3) an awareness of social support and 4) an awareness of self-identity. A general explanation of each factor is listed below.

\section{Social support}

Social support encompasses acts provided by the family and the social environment, in order to help an individual face their physical situation as a disabled person. The act could occur in material and 
non-material forms such as 1) motivation in living with their new physical situation, 2) understanding and accepting their disabled situation, 3) helping to ease the level of individual adjustment in relation to facing their new situation and 4) treatment during the period of physical recovery. Optimal social support will encourage and strengthen the individual when they are overcoming various problems related to their disability. On the other hand, a lack of social support, particularly from their family, will make the individual feel as though they are alone in coping with their problems. The absence of support from their family will cause the disabled person feel as though the burden that they have endured is unbearable. They will internalise all sadness, disappointment, and negative emotions and increase the threat of stress into a more serious level. The first finding supports the existing studies (Yanuarti 2006, Lestari 2007, Satiti 2011, Sanni 2011) that have proven the association between resilience and social support.

\section{Psychological intervention}

Psychological intervention is the term used to describe several activities provided by specific parties to an individual who has experienced a physical change in order for them to recover their emotional state. The method attempted in this study was relaxation and psychological supervision. Psychological interventions also help individuals to regain a measure of serenity by neutralising negative emotions. Not only to accelerate their mental health recovery, a psychological intervention could indirectly be helpful to support the individual when facing an attack of physical pain. An intervention would be easier to receive by involving a companion who has experienced a similar situation. For instance, a resilient disabled person, as they could display themselves as a real example of a successful attempt to adjust to a new situation. Social preception is a process used to interpret and evaluate the assessed person regarding their behaviour, quality and condition in order to build up an image of the person. In building perception from a selected stimulus, all aspects in the individual are actively involved, other than the stimulus background and the stimulus itself (Sarwono 2002).

\section{The presence of a source of inspiration}

A source of inspiration originates from a disabled person who has been able to get through their hardest moments and survive. Regardless of their disability, this type of individual group has managed to accomplish their duties and responsibilities and also generates an income. They are also fuelled by optimism and refuse to give up even though they have encountered many difficulties. The participants in this research stated that inspiration has provided them with hope and strengthened their motivation as a newly-disabled person. Inspiration also helps the individual to have a role model and to adapt, inspired by parties who have experienced a similar situation. Individuals learn not to give up, no matter how hard the situation is. In relation to this concept, the learning process is related to the social learning process developed by Bandura (1977) which is still relevant to date. According to Bandura (1977), conducting an observation is one learning method (observational learning). The presence of a 'model' which is accessible for a disabled individual could lead to an observation to use to produce a similar pattern of behaviour.

\section{Public facilities for disabled people}

Public facilities should also consider meeting the needs of disabled people such as buildings accessible for a person who is using a wheelchair, public transportation with facilities for a disabled person or an elevator to help them access buildings. The availability of public facilities will help a disabled person complete their daily activities, increasing their accessibility, and minimise the social gap between a disabled person and society in general. The situation will help to decrease the psychological burden endured by a disabled person. In contrast, the lack of public facilities for a disabled person will exclude them from their surroundings because they will only have access to a limited number of spaces, thus widening the gap between disabled people and the surrounding society.

\section{Religiosity}

Religious is the interpretation of religious values in life. The value is not only expressed through prayer rituals, but also through internalising the faith-based individual behaviour on a daily basis. 
A high level of religiosity will help them when encountering negative perception when facing a difficult situation. Therefore, religiosity is a protective factor since it plays a vital role in helping the individual to accept their new condition, no matter how hard it may be. Iqbal (2012) and Pertiwi (2012) researched the relationship between religiosity and resilience.

\section{Willingness to learn}

Learning is a method of empowering people. The learning process allows an individual to find a new way to conduct their activities, to better perform their social role, to regenerate their income or to strengthen the individual capability to manage themselves better. The willingness to learn is a real action, an implication of growing social support, a psychological intervention received by the subject, and drawn from interactions with inspiring people. Encouragement and motivation from other people does not have that much of an influence if the individual does not have the willingness to start and complete real actions. Any methods gained from an inspiring person would be useless if the person does not want to apply it in their life. Good willingness to learn will facilitate an individual when exploring their competencies, developing their capabilities and strengthening their mental state to eliminate discrimination. Finally, the learning process will increase the individual's hope and their future related to living with disability. Thus, the willingness to learn is another protective factor involved in creating individual resilient behaviour.

\section{Awareness of social support}

In many cases, individuals who end up with trauma often face pressure and a lack of support, help and motivation sent by the people in their surroundings. This act will influence the individual's perception and responses when facing their problem. Based on the existing data, the researcher identified and highlighted the importance of the self-awareness of social support as a separate factor from social support. High awareness of social support is an internal protective factor developed by the individual. An awareness of attention and motivation from friends increases the individual's objectivity when assessing the situation. It also creates energy that can be used to overcome sadness, disappointment, or self-insecurity.

\section{Awareness of self-identity}

Awareness of self identity was the last protective factor identified in this research. Such awareness brings the individual to a state of realisation that there are responsibilities that need to be fulfilled. Responsibilities do not only regard family members but also relate to their multiple roles in the context of other activities. An individual that is married has a bigger role and responsibility in the family. An awareness of identity and responsibility contributes to the attempt to resist shame, insecurity and anxiety. This type of awareness encourages individuals to do the activities that they may have previously considered impossible. However, it does not mean that a disabled person who has not been married is not influenced by the awareness of self-identity factor. Awareness of selfidentity will strengthen the individual in order for them to take a possible step away from stress.

Protective factors play an influential role in reducing anxiety during the adaptation process in individual who are new to having a disability. This factor helps the individual to manage the negative perception of disability until the individual can achieve balance in their emotional state and reduce the intensity of the various stress responses. Research shows that this protective factor had helped the individual to open themselves up to new opportunities to gain achievements in their life (Kalil 2003).

As explained in Table 2, not all of the identified protective factors are developed in the individual in one go. Differences between one person and another might occur during the resilience process based on their experience, family and culture. As an example; one participant shows that religion played a dominant part in their resilience process, while another participant showed that family support was the essential factor in coping with a breakdown even though all of the factors are related to one another. 
The identification of the eight protective factors in this research has highlighted on important notes to help a newly disabled person achieve resilience. The research findings will contribute to strengthening the external and internal protective factor implementation. Based on the participants' experience, the external protective factors that should be given earlier are related to family preparation, as it is the main supporting environment during the individual resilience process. Moreover, the probability of stress should be reduced significantly after other burdening feelings have occurred.

Table 2.

Dominant protective factors in the research participants

\begin{tabular}{|c|c|c|c|c|c|c|c|c|}
\hline \multirow{2}{*}{ Protective factors } & \multicolumn{8}{|c|}{ Participant } \\
\hline & 1 & 2 & 3 & 4 & 5 & 6 & 7 & 8 \\
\hline \multicolumn{9}{|l|}{ External protective factors } \\
\hline 1. Social support & $\sqrt{ }$ & $\sqrt{ }$ & $\sqrt{ }$ & $\sqrt{ }$ & $\sqrt{ }$ & $\sqrt{ }$ & $\sqrt{ }$ & $\sqrt{ }$ \\
\hline 2. Psychological intervention & & $\sqrt{ }$ & $\sqrt{ }$ & $\sqrt{ }$ & & & & $\sqrt{ }$ \\
\hline 3. The presence of a source of inspiration & & $\sqrt{ }$ & $\sqrt{ }$ & $\sqrt{ }$ & $\sqrt{ }$ & & & $\sqrt{ }$ \\
\hline 4. Public facilities for a disabled person & $\sqrt{ }$ & $\sqrt{ }$ & & & & & & \\
\hline \multicolumn{9}{|l|}{ Internal protective factors } \\
\hline 1. Religiosity & $\sqrt{ }$ & $\sqrt{ }$ & & $\sqrt{ }$ & $\sqrt{ }$ & & $\sqrt{ }$ & \\
\hline 2. Willingness to learn & $\sqrt{ }$ & & $\sqrt{ }$ & & & $\sqrt{ }$ & $\sqrt{ }$ & $\sqrt{ }$ \\
\hline 3. Awareness of social support & $\sqrt{ }$ & $\sqrt{ }$ & $\sqrt{ }$ & $\sqrt{ }$ & $\sqrt{ }$ & $\sqrt{ }$ & $\sqrt{ }$ & $\sqrt{ }$ \\
\hline 4. Awareness of self-identity & $\sqrt{ }$ & $\sqrt{ }$ & $\sqrt{ }$ & $\sqrt{ }$ & $\sqrt{ }$ & $\sqrt{ }$ & $\sqrt{ }$ & $\sqrt{ }$ \\
\hline
\end{tabular}

The identification of the 8 protective factors in this research has highlighted on important notes to help a newly disabled person achieve resilience. The research findings will contribute to strengthening the external and internal protective factor implementation. Based on the participants' experience, the external protective factors that should be given earlier are related to family preparation, as it is the main supporting environment during the individual resilience process. Moreover, the probability of stress should be reduced significantly after other burdening feelings have occurred.

Two activities involved in strengthening the external protective factors involves (1) the optimisation of parental support through activities designed in a specific intervention module and (2) early supervision to help the individual reduce pressure and stress, strengthening the religious aspects and to apply various therapy techniques such as relaxation and meditation. Therapy should be done simultaneously.

Strengthening the external protective factors combined with internal protective factors contains advanced supervision measures. Advanced supervision is intended to improve the individual willingness to learn, an awareness of social support and an awareness of responsibility. In this state, the presence of a resilient disabled person is important in order to increase the motivation and inspiration of the recently disabled individual so then they refuse to give up on the current situation.

\section{Conclusion}

The research findings have addressed the proposed research question. There are eight protective factors that play a significant role in a disabled person achieving resilience in response to the alteration of their physical abilities. The eight factors consist of four external protective factors (social support, psychological intervention, the presence of the source of inspiration and public facilities for a disabled person) and four internal protective factors (religiosity, willingness to learn, awareness of social support, and awareness of self-identity). This research has also proposed a recommendation to implement the following proper measures to help a newly disabled person to achieve resilient behaviour through strengthening the identified protective factors. 


\section{References}

Baihaqi YD (2007) Cinta yang Utuh: Pengalaman-Pengalaman Kecacatan. Bandung: DAR! Mizan. Bandura A (1977) Social Learning Theory. New Jersey: Prentise Hall.

Boyatzis RE (1998) Transforming Qualitative Information: Thematic Analysis and Code Development. Thousand Oaks, CA: Sage Publications.

Charmaz K (1991) Good Days, Bad Days: The Self in Chronic Illness and Time. New Jersey: Rutgers University Press.

Cohen RM (2008) Strong at The Broken Places: Voices of Illness, a Chorus of Hope. [Accessed 20 February 2014]. http://www.harpercollins.com.au/books.

Ferrasta T (2010) That's All. Jakarta: Cicero Publishing.

Fuad B (2010) Difabel: Sebuah Simbol Perlawanan Ideologis. [Accessed 8 October 2010]. http:// cakfu.info/2010/08.

Hendriani W (2006) Keterlibatan Orangtua dalam Pendidikan Anak Berkebutuhan Khusus. Laporan Penelitian EWMP (Tidak Diterbitkan). Surabaya: Fakultas Psikologi Universitas Airlangga.

Hendriani W (2007) Resiliensi Keluarga dengan Orangtua Berkebutuhan Khusus. Laporan Penelitian EWMP (Tidak Diterbitkan). Surabaya: Fakultas Psikologi Universitas Airlangga.

Hendriani W (2008) Eksplorasi Faktor-Faktor Protektif Resiliensi pada Keluarga Khusus. Laporan Penelitian EWMP (Tidak Diterbitkan). Surabaya: Fakultas Psikologi Universitas Airlangga.

Hendriani W (2012) Penerapan Dua Langkah Analisis Tematik dalam Penelitian Tentang Resiliensi pada Individu Tunarungu. Laporan Penelitian EWMP (Tidak Diterbitkan). Surabaya: Fakultas Psikologi Universitas Airlangga.

Inoue M (2006) Aku Terlahir 500 gr dan Buta. Jakarta: PT Elex Media Komputindo.

Inoy R (2012) GBS Tidak Menghalangi Langkahku: Kisah Nyata Ogest, Mantan Penyanyi Cilik Pengidap Guillain Barre Syndrome. Jakarta: PT Gramedia Pustaka Utama.

Iqbal M (2012) Hubungan antara Self Esteem dan Relisiusitas dengan Resiliensi pada Remaja di Yayasan Himmata. Skripsi, UIN Syarif Hidayatullah, Jakarta.

Kalil A (2003) Family Resilience and Good Child Outcomes. Wellington: Ministry of Social Development.

Kasim ER (2007) Masalah Penyandang Cacat dan Aspek Budaya. [Accessed 8 October 2014]. http:// evakasim.multiply.com.

Kasim ER (2007) Tinjau Kembali Rehabilitasi Penyandang Cacat. [Accessed 8 October 2014]. http:// evakasim.multiply.com.

Lee HA (2008) Diari Hee Ah Lee - Pianis Berjari Empat. Jakarta: PT Elex Media Komputindo.

Lestari K (2007) Hubungan Antara Bentuk-bentuk Dukungan Sosial dengan Tingkat Resiliensi Penyintas Gempa di Desa Canan, Kecamatan Wedi, Kabupaten Klaten. Skripsi, Universitas Diponegoro, Semarang.

Masten AS (2001) Ordinary magic: Resilience processes in development. American Psychologist 53 (3):227-238.

Olson DH \& DeFrain J (2003) Marriage and Families. Boston : McGraw-Hill.

Ototake H (2001) No One's Perfect. Jakarta: PT Elex Media Komputindo.

Pertiwi M (2012) Dimensi Religiusitas dan Resiliensi pada Residen Narkoba di BNN Lido. Skripsi, UIN Syarif Hidayatullah, Jakarta.

Peters RD, Leadbeater B, \& McMahon RJ (2005) Resilience in Children, Families, and Communities: Linking Context to Practice and Policy. New York: Kluwer Academic / Plenum Publishers. 
Reivich K \& Shatte A (2002) The Resilience Factor: 7 Essential Skills for Overcoming Life's Inevitable Obstacles. New York: Broadway Books.

Richardson GE (2002) The metatheory of resilience and resiliency. Journal of Clinical Psychology $58(3): 307-321$.

Sanni IK (2011) Hubungan Dukungan Sosial dengan Resiliensi pada Remaja SMU 1 Pangkah Tegal. Skripsi, Universitas Islam Indonesia, Yogyakarta.

Sarwono SW (2002) Psikologi Sosial. Jakarta: Balai Pustaka.

Satiti AD (2011) Hubungan Antara Dukungan Sosial dengan Tingkat Resiliensi pada Pengangguran Usia Remaja Akhir. Skripsi, Universitas Airlangga, Surabaya.

Setyawati A (2012) I Know I Can: Kisah Orang-Orang Sukses dengan Keterbatasan Fisik. Jakarta: PT Suka Buku.

Tarsidi D (2008) Model Konseling Rehabilitasi Bagi Individu Tunanetra Dewasa (Dikembangkan Berdasarkan Studi Kasus Terhadap Individu Tunanetra Dewasa yang Berhasil). Dissertation, Sekolah Pasca Sarjana Universitas Pendidikan Indonesia, Bandung.

Tugade MM \& Fredricson BL (2004) Resilient individuals use positive emotions to bounce back from negative emotional experiences. Journal of Personality and Social Psychology 86 (2):320-333.

Ungar M (2003) Qualitative contributions to resilience research. Qualitative Social Work 2 (1):85102.

Ungar M (2004) A constructionist discourse on resilience: Multiple contexts, multiple realities among at risk children and youth. Youth and Society 35 (3):341-365.

Utomo M (2012) 2 Detik Mengubah Hidup: Ketika Tuhan Berkehendak Saya Harus Berjalan dalam Kelumpuhan. Solo: Metagraf.

VanBreda AD (2001) Resilience Theory: A Literature Review. Pretoria: South African Military Health Service, Military Psychological Institute, Social Work Research and Development.

Winasti M (2012) Motivasi berwirausaha pada penyandang disabilitas fisik. Emphaty 1 (1).

Yanuarti C (2006) Hubungan Dukungan Sosial dengan Ketahanan Menghadapi Masalah. Skripsi, Universitas Muhammadiyah Malang, Malang.

Yoshida KK (1993) Reshaping of self: A pendular reconstruction of self and identity among adults with traumatic spinal cord injury. Sosiology of Health and Illness 15 (2).

Yudistia A (2011) Perempuan Tunarungu Menembus Batas. Jakarta: U pnormals Publishing. 